\title{
Seed yield and quality as affected by weed management practices in bitter gourd
}

\author{
P. Anitha*, S. Nirmala Devi and P. Sainamole Kurian \\ All India-Co-ordinated Vegetable Improvement Project, College of Horticulture, Kerala Agricultural University \\ Vellanikkara, Thrissur - 680656. \\ *Email: anitha.p@kau.in
}

\begin{abstract}
Effect of weed management practices on seed yield and quality of bitter gourd var. Preethi was studied during 2016-17. The results showed that highest seed yield $(0.73 t / h a)$ was recorded in the treatment Pendimethalin @0.75 a.i. /ha plus one hand weeding at 40 DAS followed by mulching using black polythene $(0.65 t / h a)$ which were on par. The lowest seed yield $(0.18 t / h a)$ was in weedy check. Weed control efficiency was highest $(100 \%)$ in mulching with black polythene followed by application of pendimethalin +one hand weeding at 40DAS (97.97). Seed quality in terms of percentage germination (82.52), vigour index I(1924.15) and Vigour index II ( 27.24$)$ were significantly superior in mulching with black polythene and was on par with weed free check and application of Pendimenthalin + one hand weeding at 40 DAS. Highest seedling length $(26.10 \mathrm{~cm})$ and seedling fresh weight $(2.45 \mathrm{~g})$ were also recorded in the same treatment. However, there was no significant difference between treatments for seedling dry weight.
\end{abstract}

Key Words: Bitter gourd, weed, seed quality, seed yield, germination, vigour index

\section{INTRODUCTION}

Seed quality plays an important role in the production of agronomic and horticultural crops. Characteristics such as trueness to variety, germination percentage, purity, vigour, and appearance are important to farmers planting crops. A close understanding of weed management is essential for obtaining higher crop yields and preserving seeds quality. Weed management is the most important aspect while producing good quality seed and maximizing crop yields. Producing a competitive and high-yielding crop begins with the seed. It is important to begin with seed that will germinate and emerge uniformly and quickly, producing a vigorous seedling that can compete with emerging weeds (Duary, 2014). Herbicides are chemicals that are normally used to combat weeds present in a crop and an ideal herbicide should be highly effective at the same time conserve seed quality. Rapid germination of seeds and emergence of seedlings is an important determinant of successful crop establishment (Hydecker et al., 1973). Seed quality is one of the key factors affecting successful farming. Poor quality seeds generally show decrease in germination and emergence of seedlings. Weed management in seed production is important to avoid weed competition and to get seeds of high quality and purity. Vegetable seed growers employ various weed management practices. The effect of weed management practices on efficiency of weed control and purity and quality of produced seeds is a matter of concern to the seed growers. Therefore, the present study was undertaken to find out the effect of various weed management practices on the seed yield and seed quality in bitter gourd var. Preethi.

The study was conducted with nine treatments and three replications in randomized complete block design in the year 2016-17. The plot size consisted of $4.5 \mathrm{mx} 3 \mathrm{~m}$. The experiment consisted of following treatments namely,

$\mathrm{T}_{1}$ - Pre emergent application of Pendimethalin@0.7프 a.i/ha

$\mathrm{T}_{2}-\mathrm{T}_{1}$ +one hand weeding at 40DAS

$\mathrm{T}_{3}$ - Stale seed bed by Glyphosate @ $1 \mathrm{~kg}$ a.i./ha 15 days before sowing 
$\mathrm{T}_{4}-\mathrm{T}_{3}$ +one hand weeding at 40DAS

$\mathrm{T}_{5}$ - Mulching with black polythene

$\mathrm{T}_{6}$ - Straw mulch

$\mathrm{T}_{7}$ - Hand weeding at 20, 40, 60 DAS

$\mathrm{T}_{8}$ - Weed free check

$\mathrm{T}_{9}$ - Weedy check

The bitter gourd var. Preethi was raised during 2016-17 as per the Kerala Agricultural University Package of Practices Recommendations, Crops (2011). Percentage weed control was estimated over the weedy check, by counting the number of weeds present in each plot. Ripe fruits were harvested for seed extraction, seeds extracted were dried to moisture content of $8.0 \%$ and per hectare yield was computed and seeds stored in plastic containers in the AC with a temperature of $22 \pm 5^{\circ} \mathrm{C}$. Stored seeds were kept for germination study after three months in a sterile sand medium and percentage germination was computed. Twenty days after germination, twenty seedlings were up rooted and average fresh weight, seedling length, were noted and kept for drying in an oven. After attaining constant weight, average seedling dry weight was measured. Seed quality parameters such as vigour index I and vigour index II were estimated as detailed by per Abdul- Baki and Anderson, 1972.

The effect of weed management practices on seed yield and quality is presented in Table 1. Highest seed yield $(0.73 \mathrm{t} / \mathrm{ha})$ was recorded in the treatment Pendimethalin@0.75 a.i./ha + one hand weeding at 40 DAS $\left(\mathrm{T}_{2}\right)$ followed by mulching using black polythene $(0.65 \mathrm{t} / \mathrm{ha})\left(\mathrm{T}_{5}\right)$, straw mulch(T6) ( $\left.0.56 \mathrm{t} / \mathrm{ha}\right)$ and these were on par. The lowest seed yield $(0.18 \mathrm{t} /$ ha) was in weedy check $\left(\mathrm{T}_{9}\right)$ followed by T3 (Stale seedbed by Glyphostae@1.0kga.i//ha 15 days before sowing $(0.36 \mathrm{t} / \mathrm{ha})$. Application of Pendimethalin as preemergent @0.75kg a.i $/$ ha alone (T1) for weed control, recorded seed yield on par $(0.54 \mathrm{t} / \mathrm{ha})$ with weed free check (T8) (0.51t/ha). It was clear that application of herbicides alone for weed control (T1 and T3) resulted in reduction in seed yield in bitter gourd. Similar results are reported by Young and Yenish (2000) in wheat, Smith and Wilson (2002) in Phaseolus vulgaris, Khan, et al., (2006) in green gram. Weed control efficiency was $100 \%$ in mulching with black polythene $\left(\mathrm{T}_{5}\right)$ followed by $\mathrm{T}_{2}$, (Pendimethalin +1 hand weeding at 40DAS) i.e. $97.97 \%$ which were on par. The remaining treatments differed significantly with respect to efficiency of weed control. The lowest weed control efficiency (54.53) was noted in weedy check $\left(\mathrm{T}_{9}\right)$. Bowman et al., (1986) and Ismail et al., (2009), reported similar results.

Various weed management treatments affected seed quality significantly. Mulching with black polythene $\left(\mathrm{T}_{5}\right)$ was significantly superior with respect to percentage germination (82.52) and vigour index I (1924.15) and vigour index II (27.24) and this was on par with Pendimenthalin + one hand weeding at 40 DAS $\left(\mathrm{T}_{2}\right)$. Highest seedling length $(26.10 \mathrm{~cm})$ and seedling fresh weight $(2.45 \mathrm{~g})$ were also recorded in the same treatment. Seed quality parameters such as percentage germination $(58 \%, 45.9 \%)$, seedling dry weight, $(0.35 \mathrm{~g}, 0.29 \mathrm{~g})$, vigour index I $(1040.60,1146.82)$ and vigour index II $(20.06,13.41)$ respectively were significantly low in $\mathrm{T} 1$ and $\mathrm{T} 3$ treatments where herbicide only were used for weed control. It showed that application of herbicide alone considerably reduced the seed yield and other seed quality parameters in bitter gourd. Shalno and Zheljazkov (2011) also report similar results in coriander, Shaw and Ratnayake (2017) in Cassia obtusifolia, where normal seedlings, seedling emergence and seedling length were considerably reduced by herbicide application. It was also clear that herbicide application along with one hand weeding at 40 DAS (T2 and T4) recorded seed quality characters such as germination $\%(74.7 \%, 74.12 \%)$ seedling length $(24.85 \mathrm{~cm}, 24.82 \mathrm{~cm})$, seedling fresh weight $(2.14 \mathrm{~g}$, $2.19 \mathrm{~g})$ seedling dry weight $(0.36 \mathrm{~g}, 0.32 \mathrm{~g})$, vigour index I $(1854.00,1638.47)$ and vigour index II $(26.61,23.52)$ which are on par. However, T2 and T4 differed significantly with respect to seed yield and percentage weed control where T2 performed superior in these characters. Similar results were obtained by Drew. J.L and Robert, G. W (2005) where they found that pendimenthalin applied as pre-emergent herbicide provided acceptable weed control in the irrigated chickpea. However, seedling dry weight did not vary significantly in various weed control treatments. 
Table.1. Effect of weed management treatments of seed quality in bitter gourd var. Preethi

\begin{tabular}{|c|c|c|c|c|c|c|c|c|}
\hline Treatments & $\begin{array}{l}\text { Seed } \\
\text { yield } \\
\text { t/ha }\end{array}$ & $\begin{array}{c}\text { Germi- } \\
\text { nation } \\
(\%)\end{array}$ & $\begin{array}{l}\text { Seedling } \\
\text { length } \\
\text { (cm) }\end{array}$ & $\begin{array}{l}\text { Seedling } \\
\text { fresh } \\
\text { weight } \\
\text { (g) }\end{array}$ & $\begin{array}{l}\text { Seedling } \\
\text { dry } \\
\text { weight } \\
(\mathrm{g})\end{array}$ & $\begin{array}{l}\text { Vigour } \\
\text { index I }\end{array}$ & $\begin{array}{l}\text { Vigour } \\
\text { index II }\end{array}$ & $\begin{array}{c}\% \\
\text { weed } \\
\text { control }\end{array}$ \\
\hline $\begin{array}{l}\text { T1 } \\
\text { Preemergent } \\
\text { application of } \\
\text { Pendimethalin@0.75 } \\
\text { a.i/ha }\end{array}$ & 0.54 & 58.00 & 17.90 & 2.00 & 0.35 & 1040.60 & 20.06 & 88.57 \\
\hline $\begin{array}{l}\mathrm{T} 2- \\
\mathrm{T} 1+\text { one hand } \\
\text { weeding at 40DAS }\end{array}$ & 0.73 & 74.70 & 24.85 & 2.14 & 0.36 & 1854.00 & 26.61 & 97.97 \\
\hline $\begin{array}{l}\text { T3 } \\
\text {-Staleseedbed by } \\
\text { Glyphosate @ 1kg } \\
\text { a.i./ha 15 days } \\
\text { before sowing }\end{array}$ & 0.36 & 45.90 & 19.74 & 2.19 & 0.29 & 1146.82 & 13.41 & 67.50 \\
\hline $\begin{array}{l}\text { T4 } \\
\text { T3+one hand weeding } \\
\text { at 40DAS }\end{array}$ & 0.48 & 74.12 & 24.82 & 1.91 & 0.32 & 1638.47 & 23.52 & 72.73 \\
\hline $\begin{array}{l}\text { T5 } \\
\text { Mulching with black } \\
\text { polythene }\end{array}$ & 0.65 & 82.52 & 26.10 & 2.45 & 0.33 & 1924.15 & 27.24 & 100.00 \\
\hline $\begin{array}{l}\text { T6 } \\
\text { Straw mulch }\end{array}$ & 0.56 & 51.58 & 22.80 & 2.44 & 0.23 & 1178.80 & 11.66 & 91.48 \\
\hline $\begin{array}{l}\text { T7 } \\
\text { Hand weeding at } \\
20,40,60 \mathrm{DAS}\end{array}$ & 0.49 & 62.67 & 16.85 & 2.00 & 0.34 & 1057.20 & 21.20 & 71.73 \\
\hline $\begin{array}{l}\text { T8 } \\
\text { Weed free check }\end{array}$ & 0.51 & 70.90 & 19.75 & 1.15 & 0.42 & 1185.77 & 29.66 & 81.43 \\
\hline $\begin{array}{l}\text { T9 } \\
\text { Weedy check }\end{array}$ & 0.18 & 62.77 & 16.83 & 2.11 & 0.32 & 1057.73 & 20.26 & 54.43 \\
\hline $\mathrm{CD}(P=0.05)$ & 0.13 & 4.74 & 3.54 & 0.27 & NS & 238.73 & 7.43 & 3.08 \\
\hline
\end{tabular}

The study revealed that there was significant influence of various weed management treatments on seed yield and quality of bitter gourd. There was $100 \%$ weed control efficiency in mulching with black polythene $\left(\mathrm{T}_{5}\right)$. Among the treatments with herbicides and its combinations, Pendimethalin + one hand weeding at 40DAS gave $97.7 \%$ weed control efficiency along with high seed yield and seed quality parameters and hence can be recommended for weed control in the seed production plot of bitter gourd (Fig.1 and Fig.2).

\section{ACKNOWLEDGMENT}

The authors are thankful to the Project Coordinator, All India Co-ordinated Research Project (Vegetable Crops), Varanasi for the financial support rendered and the College of Horticulture, Kerala Agricultural University, Vellanikkara, Thrissur for the facilities provided during the course of the study. 


\section{seed yield as affected by weed management in bitter gourd}

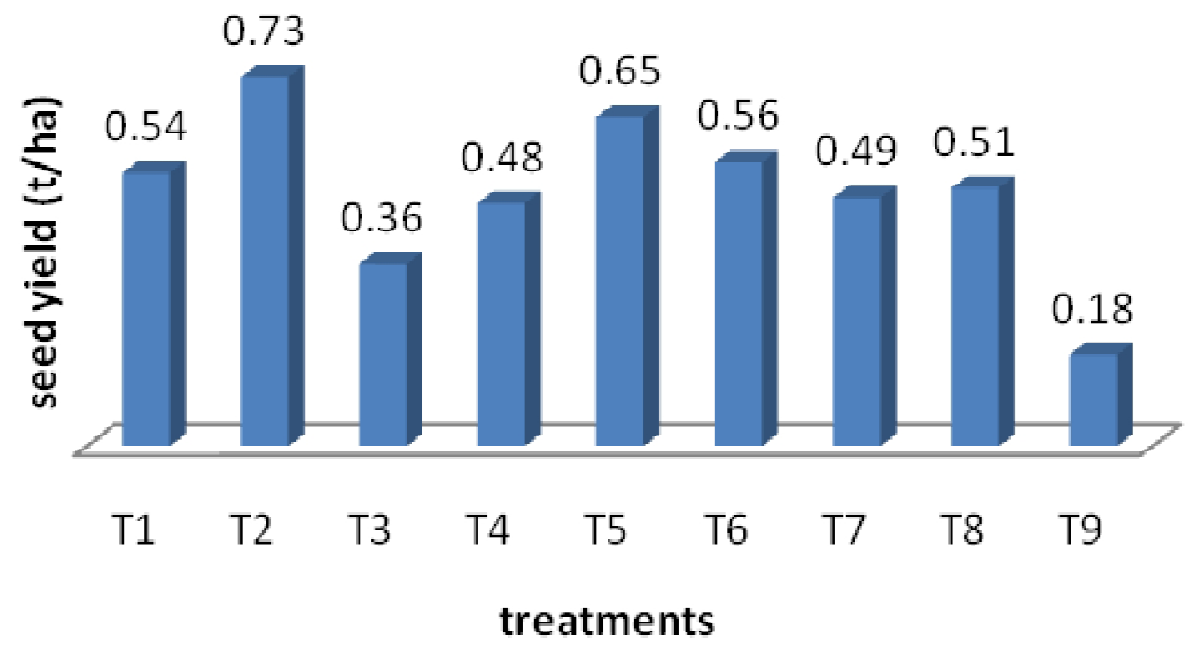

Fig.1. Seed yield affected by weed management in bitter gourd

\section{germination in bitter gourd as affected by weed management}

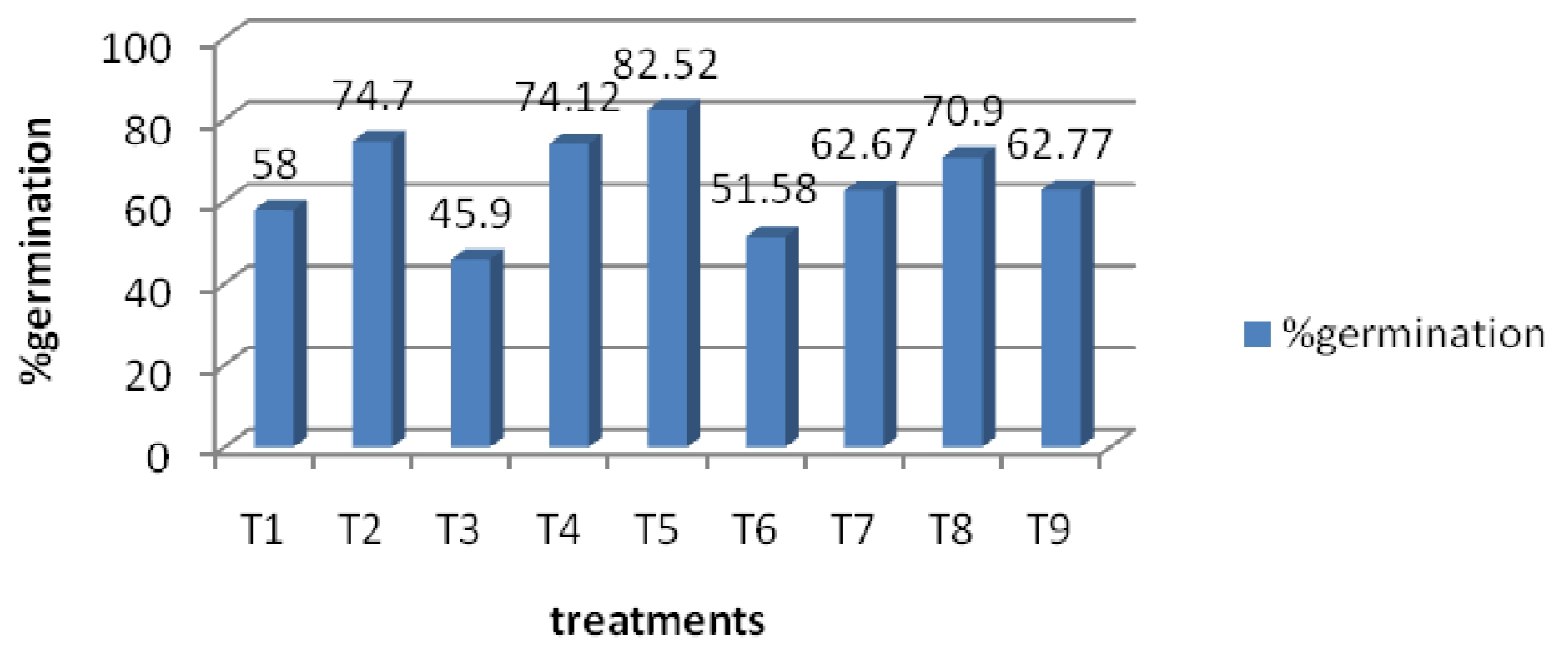

Fig.2. Germination of seeds affected by weed management in bitter gourd 


\section{REFERENCES}

Abdul- Baki and Anderson, 1972. Vigour deterioration in soybean by multiple criteria. Crop. Sci. 13:630-637.

Bowman, J.E. Hartmen, G; Mc Clay, R.P. Sinclair J.R. Hummel J.W. and Wax L.M. 1986. Effect of weed control and Row spacing in conventional tillage, reduced Tillage and Non Tillage on Soybean Quality. Plant Disease 70: 673-676

Drew. J.L and Robert. G.W. 2005. Chemical weed control in dry land and irrigated chickpea. Weed Technology: 19(4): 959-965.

Duary, B. 2014. Weed Prevention for Quality Seed Production of Crops. S ATSA Mukhapatra - Annual Technical Issue 18: 2014

Heydecker W; Higgins.J. and Gulliver R.L.1973. Accelerated germination by osmotic treatment. Natura : 246: $42-44$

Ismail.C; Atilla,Y; Yusuf.T; Leuvent.O 2009. Glyphosate reduced seed and leaf concentrations of calcium, magnesium, manganese and iron in non-glyphostae resistant soybean. European J. Agron. 31(3): 114-119
Kerala Agricultural University, 2011. Package of Practices Recommendations: Crops. Kerala Agricultural University, Thrissur, 680 656.

Khan, MS, Chaudhry,P, Wani PA, Zaidi, A 2006. Biotoxic effects of the herbicides on growth, seed yield, and grain protein of green gram. J. Appl. Sci. Environ. Management 10(3); 141-146

Shaw,D.R and Ratnayake.S 2017. Effects of HarvestAid Herbicides on Sickle pod (Cassia obtusifolia) Seed Yield and Quality. Weed Technol. 6 :(4):985-989

Shalnov.I and Zheljazkov.V. 2011. Effect of Herbicides on Yield and Quality of Coriandrum sativum L. J. Essential Oil Res. 7 :(6):633639.

Smith,J,A and Wilson R.G.2002. Influence of HarvestAid Herbicides on Dry Bean (Phaseolus vulgaris) Desiccation, Seed Yield, and Quality. Weed Technol. 16(1):109-115.

Young, F.L and Yenish ,J,P.2000. Effect of Pre harvest Glyphosate Application on Seed and Seedling Quality of Spring Wheat (Triticum aestivum). Weed Technol. 14(1):212-217.

(MS Received 31 August 2017, Revised 14 October 2018, Accepted 24 December 2018) 